\title{
Exergy-based Investigation of Various Heat Pumps for Enhancement of Their Thermodynamic Efficiency
}

\author{
VoloshchukVolodymyr \\ Department of automation of thermal processes \\ National Technical University of Ukraine "Igor Sikorsky Kyiv \\ Polytechnic Institute" \\ Kyiv, Ukraine \\ V1.Volodya@gmail.com
}

\author{
Gullo Paride \\ Technical University of Denmark" \\ Denmark \\ parigul@mek.dtu.dk
}

\begin{abstract}
The work demonstrates the results of application of the detailed advanced exergetic analysis to air-source, watersource and wastewater-source heat pumps providing space heating in the built environment. Cumulative values based on seasonal exergy destruction are used for deriving conclusions. It is shown that in the specified conditions of the investigated systems priorities for improving should be given to heat exchangers.
\end{abstract}

Keywords - advanced exergetic analysis; air-source, watersource and wastewater-source heat pumps; space heating

\section{INTRODUCTION}

The exergy-based methods provide information concerning location, magnitude and causes of thermodynamic inefficiencies in an energy-conversion system $[1,2]$.

The scope of the work is to demonstrate the application of advanced exergetic analysis to several types of heat pumps providing space heating in varying operational modes, which is typical of the built environment and caused by fluctuating outdoor conditions.

To identify the importance of the components from the thermodynamic viewpoint and priorities for improving the components the sum of the avoidable endogenous exergy destruction within the kth component $\dot{E}_{D, k}^{A V, E N}$ and of the avoidable exogenous exergy destructions within the remaining components caused by the kth component $\sum_{\substack{r=1 \\ r \neq k}}^{n-1} \dot{E}_{D, r}^{A V, E X, k}$ should be used $[1,2]$

$$
\dot{E}_{D, k}^{A V, \Sigma}=\dot{E}_{D, k}^{A V, E N}+\sum_{\substack{c=l \\ r \neq k}}^{n-1} \dot{E}_{D, r}^{A V, E X, k} .
$$

Three types of heat pumps for space heating have been investigated using the advanced exergetic analysis: air-source, water-source and wastewater-source ones.

Daily weather data within a heating season for the city of Rivne located in the western part of Ukraine have been used for the analyses. So, 24-hour time step $\tau_{n}$ are assumed for quasisteady state modelling. The variation of mean daily outdoor temperature is within the range of $-16^{\circ} \mathrm{C}$ and $10^{\circ} \mathrm{C}$. The total value of heating degree days is $3500^{\circ} \mathrm{C}$-day.
According to the obtained results the biggest value of exergy destruction in the air-source heat pump can be removed with the help of improving evaporator because the sum of avoidable endogenous and avoidable exogenous exergy destruction $E_{D, E V}^{A V, \Sigma, y r}$ in this component is equal to $1600 \mathrm{~kW} \cdot \mathrm{hr}$. These parts of exergy destruction in the condenser and compressor are equal $510 \mathrm{~kW} \cdot \mathrm{hr}$ and $440 \mathrm{~kW} \cdot \mathrm{hr}$ respectively, i.e. in 3 and 3.7 times lower than in the evaporator.

For the water-source heat pump the seasonal exergy destruction which can be avoided with the help of improving the evaporator is equal to $480 \mathrm{~kW} \cdot \mathrm{hr}$ or $47 \%$ of the avoided exergy destruction in this heat pump. Improvement in the evaporator will affect not only the endogenous avoidable exergy destruction of this component, but also the exogenous avoidable exergy destruction within the throttling valve $(100 \mathrm{~kW} \cdot \mathrm{hr}$ or $50 \%$ of the annual avoidable exergy destruction in this component) and within the compressor $(130 \mathrm{~kW} \cdot \mathrm{hr}$ or $31 \%$ of the annual avoidable exergy destruction in this component). Similar results have been obtained for the condenser, but the seasonal exergy destruction which can be avoided with the help of improving this component accounts for $33 \%$ of the avoided exergy destruction in the heat pump.

The biggest part of the sum of seasonal avoidable endogenous and avoidable exogenous exergy destruction $E_{D, k}^{A V, \Sigma, y r}$ in the wastewater-source heat pump belongs to the the wastewater heat exchanger and is equal to $730 \mathrm{~kW} \cdot \mathrm{hr}$. For the evaporator and the condenser these parts of exergy destruction are lower compared with the wastewater heat exchanger and equal 530 and $440 \mathrm{~kW} \cdot \mathrm{hr}$ respectively. In the compressor the sum of seasonal avoidable endogenous and avoidable exogenous exergy destruction $E_{D, C M}^{A V, \Sigma, y r}$ is quite small.

\section{REFERENCES}

[1] Tsatsaronis G. Strengths and limitations of exergy analysis. Proceedings of the NATO Advanced Study Institute on Thermodynamics and the Optimization of Complex Energy Systems, Neptun, Romania, July 1324, 1998. Kluwer Academic Publishers. P. 93-100.

[2] Tsatsaronis G., Morosuk T. Advanced exergy-based methods used to understand and improve energy-conversion systems. CPOTE-2016. Proceedings of the 4th International Conference on Contemporary Problems of Thermal Engineering, Gliwice - Katowice: The Silesian University of Technology Institute of Thermal Technology, September 14-16, 2016. 